\title{
Effects of Picloram and Tebuthiuron on Establishment of Ryegrass Winter Pasture
}

\section{J .R . BAUR}

Highlight: Ryegrass [Lolium perenne L. (including $L$. multiflorum Lam.)] was established in plots 75 days (and $16 \mathrm{~cm}$ rainfall) after treatment with spray and granule formulations of picloram at a rate of $3.4 \mathrm{~kg} / \mathrm{ha}$. Tebuthiuron spray and granule formulations applied at the rate of $1.1 \mathrm{~kg} / \mathrm{ha} 261$ days (and $68 \mathrm{~cm}$ rainfall) before planting provided effective weed control and allowed successful grass establishment. Tebuthiuron spray and granules at $3.4 \mathrm{~kg} / \mathrm{ha}$, however, prevented both weed growth and ryegrass establishment when applied 261 days before planting. Sufficient residues from this rate of tebuthiuron were present after 499 days (and $116 \mathrm{~cm}$ rainfall) to prevent revegetation by johnsongrass on 95\% of the treated area. The soil type in the plot area was a black clay loam classified as udic pellustert.

The first step in increasing the productivity of range and pastureland is the replacement of undesirable woody and herbaceous vegetation with high-quality grasses and forbs suited to the area. In many cases the herbicides that best control undesirable woody vegetation will impede or prevent the establishment of desirable forage. Consequently, it is necessary to develop cultural and application techniques that are compatible with the interrelated objectives of woody plant removal and forage establishment

Picloram (4-amino-3,5,6-trichloropicolinic acid) and tebuthiuron $[N[5-(1,1$-dimethylethyl)-1,3,4-thiadiazol-2yl]-N,N dimethylurea] control a wide variety of woody species, including post oak (Quercus stellata Wangenh.), blackjack oak ( $Q$. marilandica Muenchh.), sumac (Rhus copallina L.), American and winged elm (Ulmus americana L. and $U$. alata Michx.), whitebrush (Aloysia lycioides (Cham.), javalinabrush (Microrhamnus ericoides Gray), yaupon (Ilex vomitoria Ait.), Macartney rose (Rosa bracteata Wendl.), and huisache [Acacia farnesiana (L.) Willd.] (Bovey et al. 1972, 1975; Peevy 1975; Scifres and Mutz 1976; Stritzke 1976b).

Tebuthiuron has a detrimental effect on many grasses and forbs, especially when applied during conditions of active growth. Scifres and Mutz (1976) noted that acrial application of tebuthiuron $(1.1 \mathrm{~kg} / \mathrm{ha})$ in May reduced range forage production through late February, although cover the next year was improved relative to the untreated areas. Grass injury can be avoided without reducing the efficacy of the treatment by placement of granules or sprays in bands (Flynt et al. 1976) or

The author is plant physiologist, Science and Education Administration U.S. Department of Agriculture, Department of Range Science, Texas A\&M University, College Station. Texas 77843 .

The research is a contribution from SEA, U.S. Dep. Agr. and the Texas Agr. Exp. Sta., College Station 77843

This paper reports the results of research only. Mention of a pesticide in this paper does not constitute a recommendation of this product by the U.S. Dep. Agr. or the Texas Agr. Exp. Sta., nor does it imply regisiration under FIFRA.

Manuscripi received Juiy $18,1977$. granules in a grid pattern (Stritzke 1976a). March applications of tebuthiuron (up to $2.2 \mathrm{~kg} / \mathrm{ha}$ to kleingrass (Panicum coloratum L.), buffelgrass (Cenchrus ciliaris L.) and common and 'Coastal' Bermudagrass [Cynodon dactylon (L.) Pers.] did not affect forage production sampled 1 and 3 months after treatment (Baur et al. 1977). June applications reduced the yield of kleingrass and the two varieties of Bermudagrass (Baur et al. 1977).

Postemergence application of picloram temporarily reduced the yield of common and coastal Bermudagrass. Yield recovery was apparent the following season (Baur et al. 1977; Bovey et al. 1974). Bovey et al. (1972) noted a similar effect of picloram on native grasses (including little bluestem [Andropogon scoparius Michx.], brownseed paspalum [Paspalum plicatulum Michx.], Indiangrass [Sorghastrum nutans (L.) Nash.], and threeawn [Eragrostis spp.]) growing in plots treated for control of woody plants. Arnold and Santelmann (1966) reported reduced yields of sideoats grama [Bouteloua curtipendula (Michx.) Torr.], blue grama [B. gracilis (H.B.K.) Lag.], switchgrass (Panicum virgatum L.) and big bluestem (Andropogon gerardi Vitman) when up to $3.4 \mathrm{~kg} / \mathrm{ha}$ of picloram was applied in the seedling stage. As the seedlings matured, resistance to picloram increased so that similar applications to established rangeland did not reduce forage production (Arnold and Santelmann 1966).

Very little research has been reported on the effects of tebuthiuron on germination. We have found that germination of sorghum [Sorghum bicolor (L.) Moench.] and wheat (Triticum aestivum L.) seed was not impeded by an 8-hour exposure to a $10^{-3} \mathrm{M}$ solution of tebuthiuron (Baur and Bovey 1975). Preemergence applications of $0.84 \mathrm{~kg} / \mathrm{ha}$ picloram prevented the germination of sideoats grama, blue grama, big bluestem, and switchgrass (Arnold and Santelmann 1966).

The objective of this investigation was to determine the minimum time interval between application of tebuthiuron and picloram for the successful establishment of ryegrass as a winter pasture.

\section{Materials and Methods}

The plot area was a 2-ha field of black clay loam, classified as a udic pellustert located in Brazos County, Texas. The cover, predominantly johnsongrass [Sorghum halepense (L.) Pers.] was sprayed in October 1974 with $2.2 \mathrm{~kg} / \mathrm{ha}$ glyphosate [N-(phosphonomethyl)glycine] and burned early in January 1975. The site was deep disced with an offset disc and smoothed with a tandem disc during January and February 1975. A series of 66 plots, 9 - by $27-\mathrm{m}$, separated by 3 -m buffer areas, was established in early March. Duplicate plots were treated with 1.1 and $3.4 \mathrm{~kg} / \mathrm{ha}$ picloram and tebuthiuron on March 31 , June 23, July 


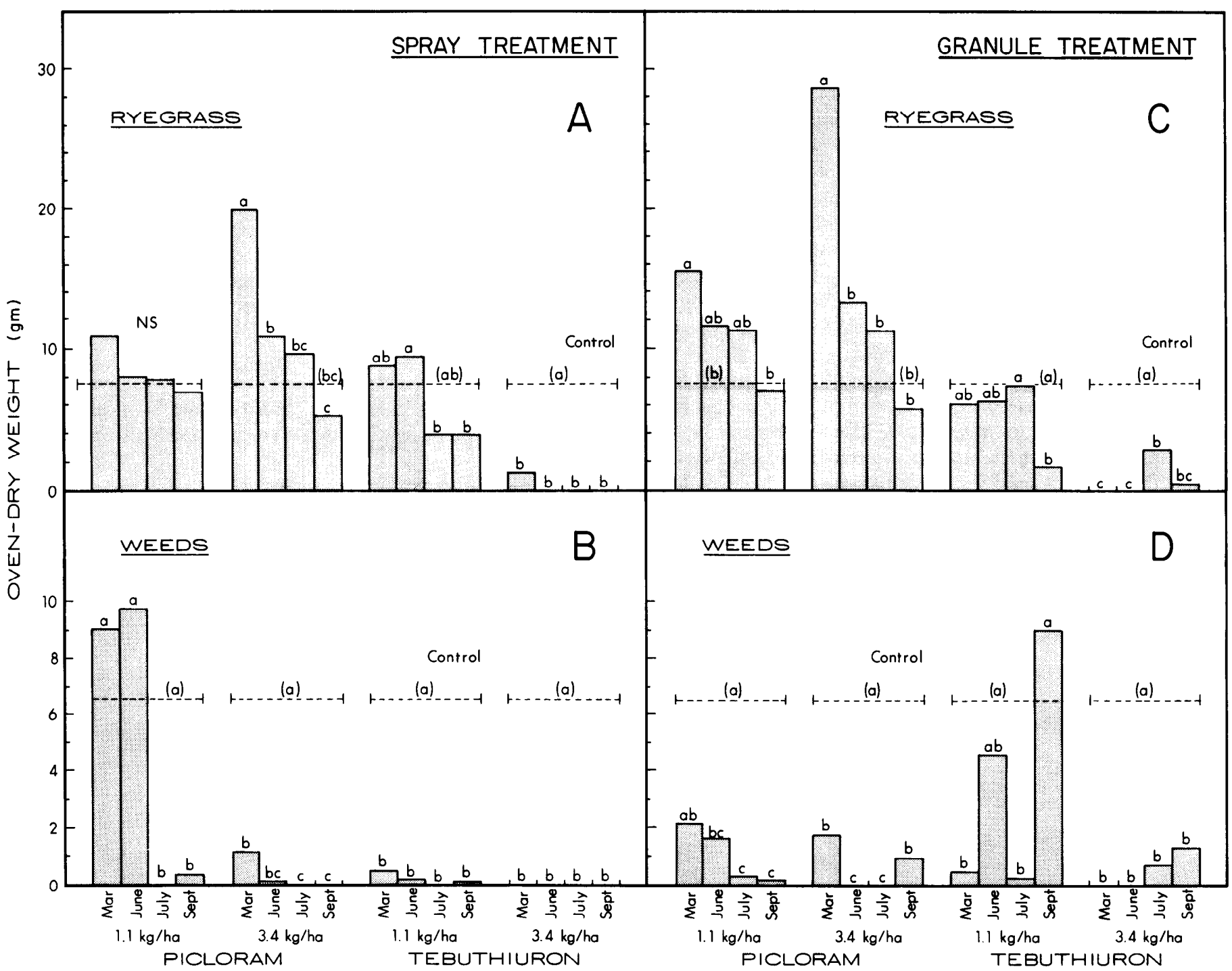

Fig. 1. Oven-dry yields of ryegrass $(A, C)$ and weeds $(B, D)$ from subplots planted in October and sampled in February. Each bar represents the average of eight 30 by $30-\mathrm{cm}$ clip areas evenly distributed among two replicate field treatments. Values representing the four treatment dates for each herbicide-rate designated by the same letter are not significantly different at the .05 level of probability.

31 , and September 24, 1975. Picloram was applied as the $10 \%$ granule and broadcast spray of the potassium salt formulation in $187 \mathrm{~L} / \mathrm{ha}$ water. Tebuthiuron was applied as the $20 \%$ granule $(1 / 8$ inch or 3.2 $\mathrm{mm}$ diam) and broadcast spray of the $80 \%$ wettable powder formulation in $187 \mathrm{~L} /$ ha water. Granules were distributed by hand; sprays were applied with a $4.5-\mathrm{m}$ tractor-mounted boom. Two untreated plots served as the control.

On August 14, 1975, the entire arca was sprayed with $2.2 \mathrm{~kg} / \mathrm{ha}$ glyphosate to control seedling johnsongrass. The field was burned early in September, followed by light discing of each plot. On October $1,1975,448 \mathrm{~kg} / \mathrm{ha}$ of 13-13-13 fertilizer was applied to the plot area. After fertilization, each large plot was subdivided into threc 9 - by $9-\mathrm{m}$ subplots. Ryegrass seed was hand broadcast at the rate of $16.8 \mathrm{~kg} / \mathrm{ha}$ to one subplot per large plot on October 14, November 10, and December 17, 1975. After seeding, each subplot was lightly disced.

Grass and weed cover were periodically evaluated throughout the winter of 1975 and spring 1976. On February 20, 1976, the subplots planted in October were intensively sampled by clipping four 30 - by $30-\mathrm{cm}$ areas that were evenly spaced on a diagonal transect. All vegetation was clipped to within $1-$ to $2-\mathrm{cm}$ of the ground. Ryegrass plants and weeds from each 30 - by $30-\mathrm{cm}$ area were separately bagged and oven dried at $105^{\circ} \mathrm{C}$ for 24 hours. The bulk fresh weight from each subplot was converted to dry weight on the basis of the moisture content of the subsamples.
In the spring of 1976, after all sampling and evaluations were complete, the ryegrass sod was broken with an offset disc and a seedbed prepared. On June 7, 1976, kleingrass was drilled to the plot area at a rate of $2.2 \mathrm{~kg} / \mathrm{ha}$ (live seed). The lack of precipitation the next 30 days resulted in crop failure and the plot area reverted to seedling johnsongrass. The johnsongrass cover of each treatment plot was evaluated on August 1976.

\section{Results and Discussion}

\section{October Planting}

Intensive sampling in late February 1976 indicated that henbit (Lamium amplexicaule L.) accounted for $90 \%$ of the annual weed cover. The remaining $10 \%$ was composed of curly dock (Rumex crispus L.), spiny sowthistle [Sonchus asper (L.) Hill], and yellow woodsorrel (Oxalis stricta L.).

Ryegrass production in subplots treated with broadcast sprays of $1.1 \mathrm{~kg} /$ ha picloram was not significantly different from the control plots regardless of date of application (Fig. 1A). Weed production in these subplots, however, was dependent on the application date of the herbicide (Fig. 1B). Subplots treated in March and June (197 and 113 days, respectively, before 
planting) had abundant stands of annual weeds whose competitive effects apparently prevented significant gains in grass production. Picloram applied later (July and September; 75 and 20 days, respectively, before planting) effectively controlled weed production (Fig. 1B), but grass production was no better than it was in control plots (Fig. 1A), probably because of picloram residues. Increasing the rate of picloram to $3.4 \mathrm{~kg} / \mathrm{ha}$ significantly increased grass production when sprays were applied in March (Fig. 1A), 197 days before planting. Later applications (June, July, and September) did not significantly affect grass production, although a trend toward decreased production is noted as the interval between treatment and seeding decreased (Fig. 1A). Picloram at $3.4 \mathrm{~kg} / \mathrm{ha}$ effectively controls annual weeds when applied as early as March (Fig. 1B). The significant increase in grass production in the Marchtreated subplots, relative to the control plots, is probably the result of removal of the competitive effects of annual weeds, whereas the downward trend in grass production in the subplots treat $d$ in June, July, and September is probably due to picloram residues (Fig. 1A).

Picloram at $1.1 \mathrm{~kg} / \mathrm{ha}$ was more effective as the granule formulation than as the spray formulation, with regard to grass production (Fig. 1C) and weed control (Fig. 1D). The significant gain in grass production (relative to the control) in subplots treated in March with $1.1 \mathrm{~kg} / \mathrm{ha}$ picloram granules is probably the result of the removal of competitive annual weeds. The higher rate of picloram granules $(3.4 \mathrm{~kg} / \mathrm{ha})$ applied in March resulted in a significant gain in grass (Fig. 1C) and appreciable reduction in weeds (Fig. 1D). Picloram residues from June, July and September treatments at both rates probably accounted for the lack of significant gain in grass production above control levels (Fig. 1C) in these treatments.

The broadcast spray application of tebuthiuron at 1.1 and 3.4 $\mathrm{kg} / \mathrm{ha}$ resulted in excellent weed control when applied as early as March (Fig. 1B). The higher rate (3.4 kg/ha), applied as early as March, virtually eliminated grass production. The $1.1 \mathrm{~kg} / \mathrm{ha}$ rate allowed grass production equivalent to that in the untreated control plots, although nonsignificant decreases in grass production occurred in subplots treated in July and September (Fig. 1A).

The effect of tebuthiuron granules at both rates was similar to that of the sprays, except that grass production in subplots receiving the $1.1 \mathrm{~kg} / \mathrm{ha}$ rate in September was significantly reduced relative to the control plots (Fig. 1C). This reduction

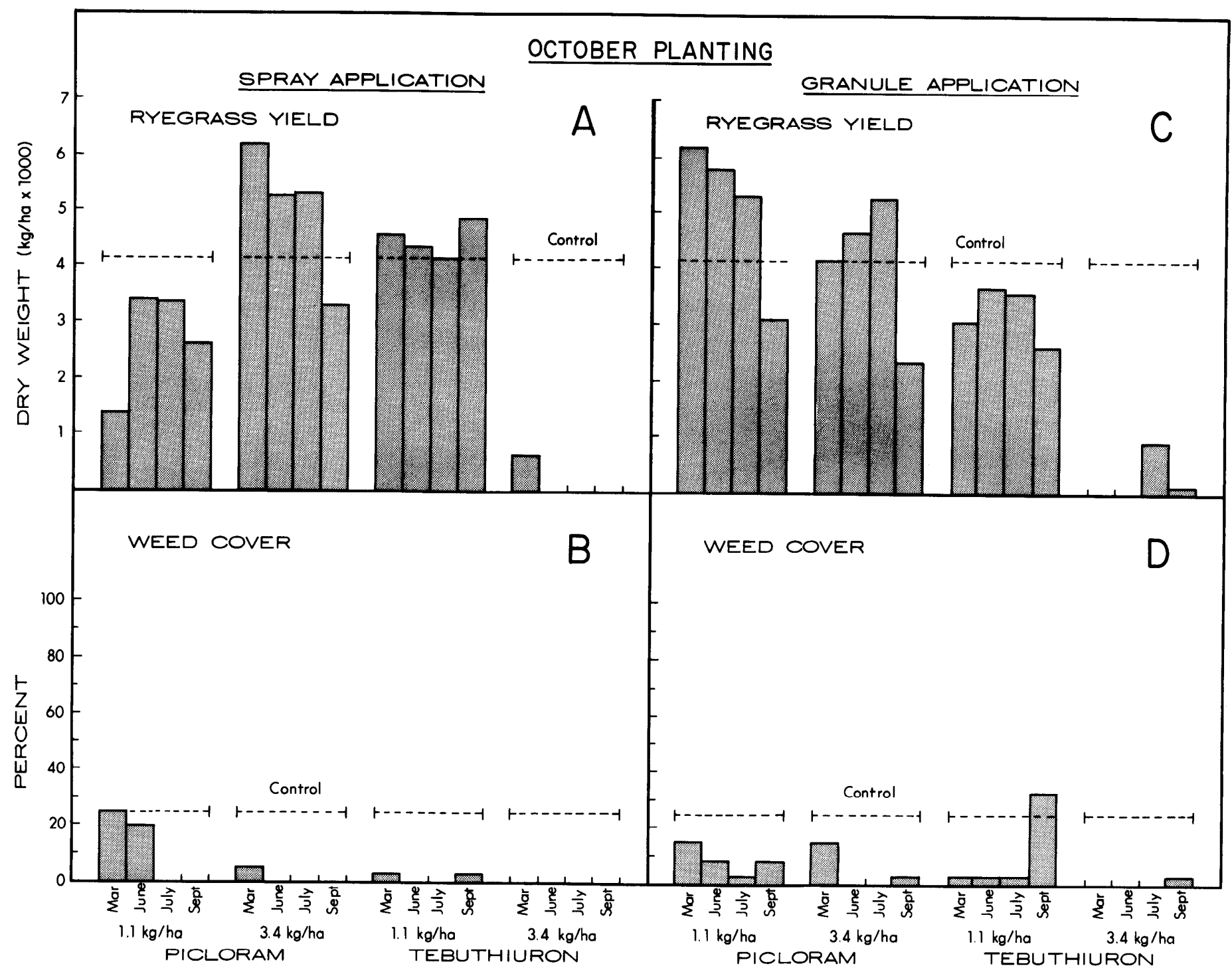

Fig. 2. Bulk yields of ryegrass $(A, C)$ and percent weed cover $(B, D)$ from subplots planted in October and harvested in April. Each bar represents the average of two subplots. 
was probably the result of weed competition. The failure of the September treatment to control weeds (Fig. 1D) may have been caused by the absence of sufficient precipitation between treatment and planting to activate the tebuthiuron granules.

Bulk harvest of the October seeded subplots on April 14, resulted in grass yields and weed cover estimates that were very similar to the grass and weed yields recorded after intensive sampling of the same subplots on February 20 (cf Fig. 1 with Fig. 2). Correlation coefficients between data recorded on the two sampling dates were 0.89 and 0.72 for weed cover and grass yield, respectively.

\section{November and December Planting}

Grass yields from control subplots seeded in November and December were relatively low, and weed cover was very high (Fig. 3 and 4). The low grass yields were probably the result of the low rainfall experienced in the 30 -day period after seeding $(2.2 \mathrm{~cm}$ after November planting; $6.0 \mathrm{~cm}$ after December planting). The competitive effects of the dense weed cover also probably contributed to the poor grass yields in control plots.

Application of picloram in either formulation and at either rate allowed grass yields that exceeded those in control plots for both the November and December plantings. The lower (1.1 $\mathrm{kg} / \mathrm{ha}$ ) rate of picloram spray applied in March and June did not adequately control weeds (Fig. 3B and 4B). The same rate of picloram granules appeared to be somewhat more persistent than the spray; weed cover for the subplots treated in June was appreciably lower with granules (Fig. 3D and 4D) than with sprays (Fig. 3B and 4B). The $3.4 \mathrm{~kg} / \mathrm{ha}$ rate of picloram in either spray and granular form provided good weed control and grass gains when applied as early as March (Fig. 3 and 4).

The $1.1 \mathrm{~kg} /$ ha rate of tebuthiuron spray and granules allowed grass yields above control levels but generally not as large as those seen for picloram-treated subplots, although weed control for March, June, and July application dates was excellent. The reduced weed control for September granule application is probably due to insufficient precipitation for activation of the granules (Fig. 3 and 4). The high rate of tebuthiuron $(3.4 \mathrm{~kg} / \mathrm{ha})$ virtually sterilized the soil for at least 261 days (March treatment, December planting, Fig. 4). A total of $68 \mathrm{~cm}$ of rainfall was recorded between this treatment and seeding (Table 1).

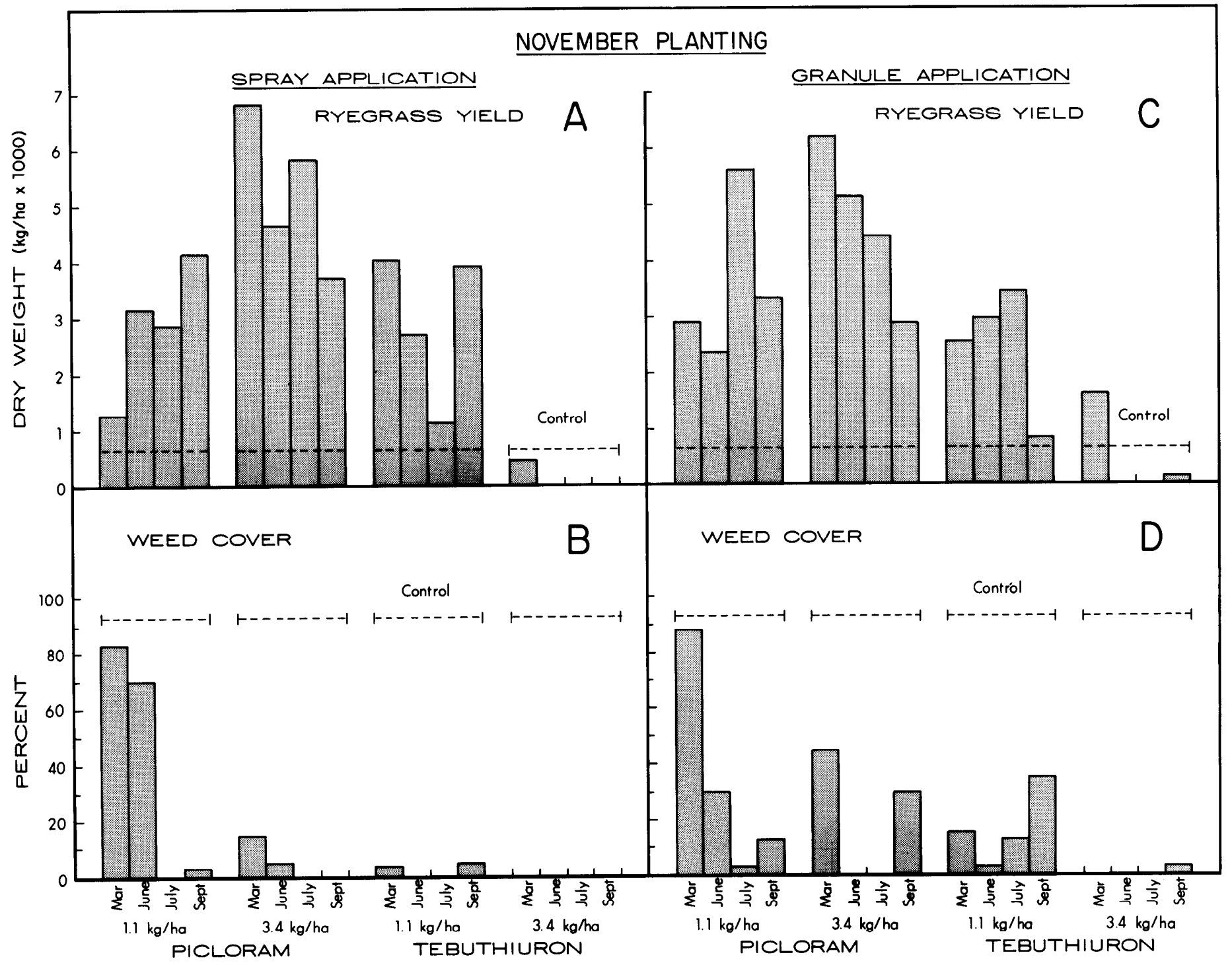

Fig. 3. Bulk yields of ryegrass $(A, C)$ and percent weed cover $(B, D)$ from subplots planted in November and harvested in April. Each bar represents the average of two subplots. 
Table 1. Days and rainfall between herbicide treatment and ryegrass planting.

\begin{tabular}{lcccc}
\hline \hline & \multicolumn{4}{c}{ Treatment date } \\
\cline { 2 - 5 } Planting date & March 31 & June 23 & July 31 & September 24 \\
\hline & 197 & 113 & Days & \\
October 14 & 224 & 140 & 102 & 20 \\
November 10 & 261 & 177 & 139 & 47 \\
December 17 & \multicolumn{5}{c}{ Rainfall (cm) } \\
October 14 & 59.4 & 24.5 & 16.1 & 0 \\
November 10 & 65.7 & 30.9 & 22.5 & 6.4 \\
December 17 & 68.0 & 33.0 & 24.7 & 8.6 \\
\hline
\end{tabular}

\section{Final Evaluation}

Evaluation of johnsongrass on the study area on August 12, 1976 indicated that at the $3.4 \mathrm{~kg} / \mathrm{ha}$ rate, both formulations of tebuthiuron were still effective in suppressing growth (Fig. 5). Precipitation for the 499-day period between the March 1975 treatment and final evaluation was $116.5 \mathrm{~cm}$. Johnsongrass cover on all plots treated at $1.1 \mathrm{~kg} / \mathrm{ha}$ was similar to that on control plots. The $3.4 \mathrm{~kg} / \mathrm{ha}$ picloram spray and granule treatments provided a small degree of johnsongrass suppression (Fig. 5).

\section{General Discussion}

Grass production in subplots treated with tebuthiuron spray and granules at $1.1 \mathrm{~kg} / \mathrm{ha}$ was generally lower than that in subplots treated with picloram spray and granules at $3.4 \mathrm{~kg} / \mathrm{ha}$ (Fig. 2,3, and 4). Because these latter treatments generally gave good weed control, competition by weeds can probably be ruled out as the cause of the difference. The increased grass production in the subplots treated with picloram at $3.4 \mathrm{~kg} / \mathrm{ha}$ might be the result of growth stimulation by very low residue levels of picloram. The absence of a similar increase in grass production in the subplots treated with picloram at $1.1 \mathrm{~kg} / \mathrm{ha}$ might result from its dissipation to nonstimulating levels. Earlier work demonstrated significant stimulation of fresh weight of corn (Zea mays L.) and sorghum by picloram at $0.25 \mathrm{ppb}$ and of wheat by picloram at $100 \mathrm{ppb}$ (Baur et al. 1970).

Although grass production in subplots treated with picloram at $3.4 \mathrm{~kg} / \mathrm{ha}$ in both formulations was generally the best noted, gains tended to decrease as the interval between treatment and

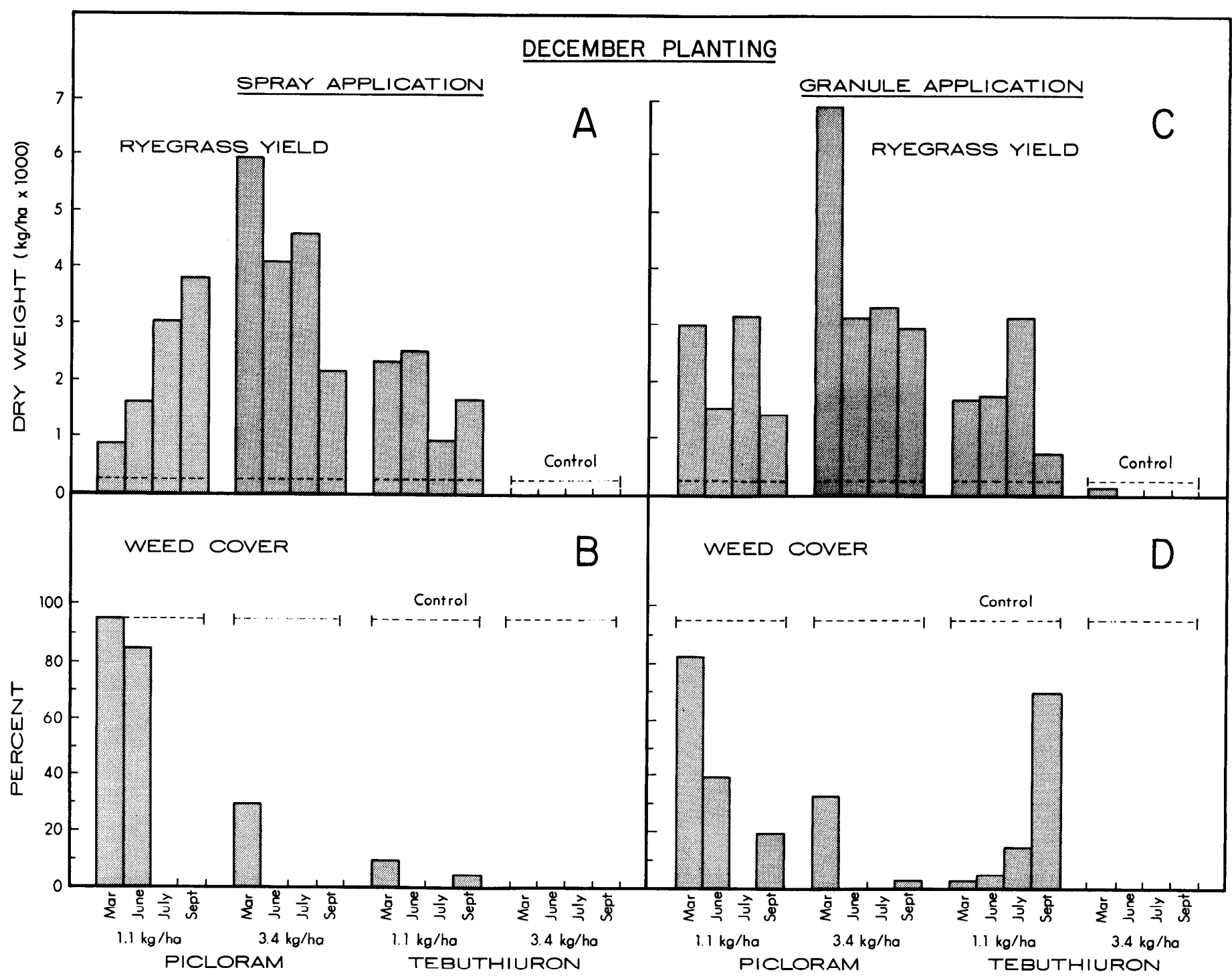

Fig. 4. Bulk yields of ryegrass $(A, C)$ and percent weed cover $(B, D)$ from subplots planted in December and harvested in April. Each bar represents the average of two subplots. 


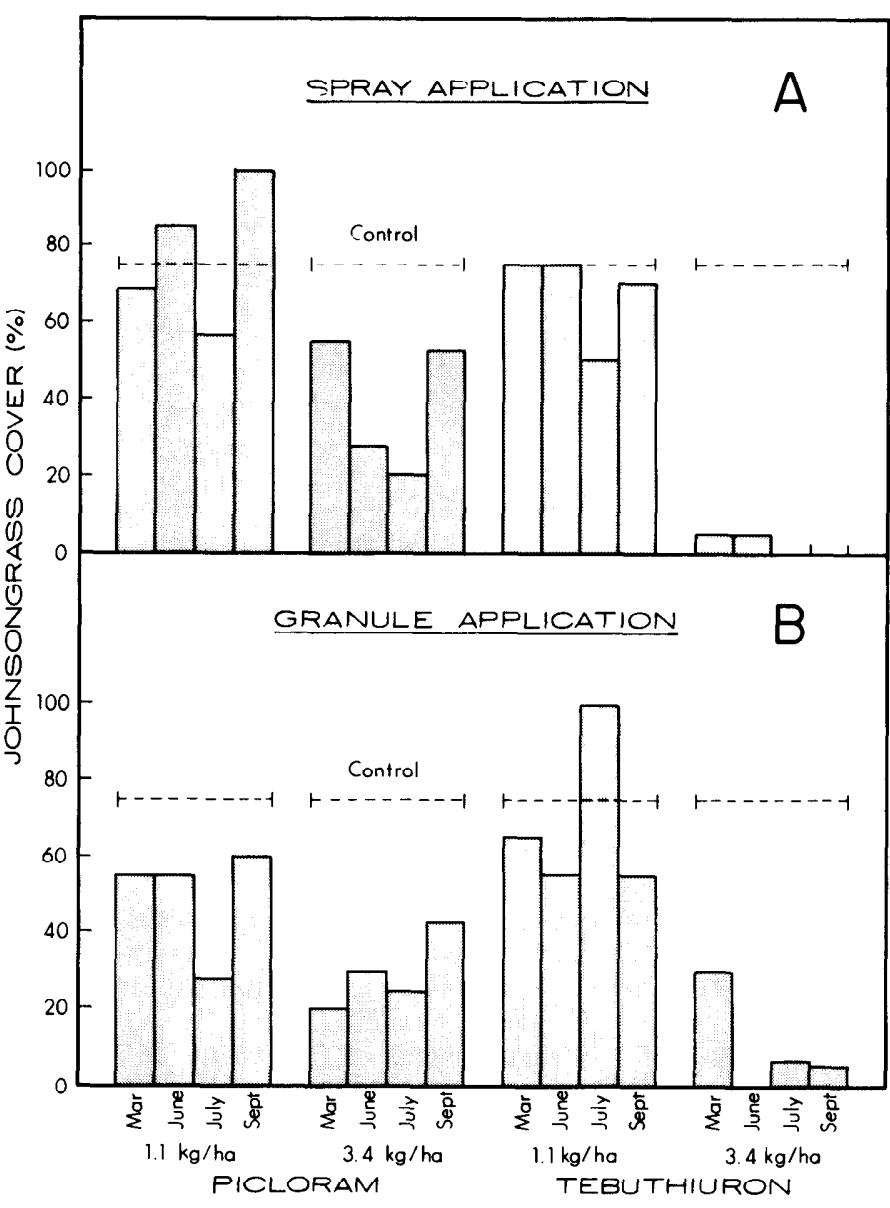

Fig. 5. Percent johnsongrass cover on plots treated with sprays $(A)$ and granules (B) from 499 (March) to 322 (September) days after treatment.

ryegrass planting decreased. The absence of weeds in these subplots eliminates competition as a cause for this decrease; it could be the result of herbicide dissipation, lessening the growth stimulation noted above. Other workers, however, have shown that preemergence applications of picloram will reduce growth of barley (Herr et al. 1966) and blue grama, sideoats grama, big bluestem, and switchgrass (Arnold and Santelmann 1966).

The low degree of weed control in plots treated in September with $1.1 \mathrm{~kg} / \mathrm{ha}$ tebuthiuron, as contrasted with the high degree of weed control in plots treated with the same rate of picloram, is probably a distribution phenomena related to the concentration of active ingredient in the granule. Distribution of a $10 \%$ picloram granule over the plot area would be better than distribution of a $20 \%$ tebuthiuron granule. A second possibility might be that the tebuthiuron granule requires more precipitation for release of the active ingredient than does the picloram granule.

The results of this study suggest that a ryegrass winter pasture can be established on a heavy clay site after preemergence treatment with picloram (spray or granules) at up to $3.4 \mathrm{~kg} / \mathrm{ha}$, or with tebuthiuron at $1.1 \mathrm{~kg} / \mathrm{ha}$, provided 75 days elapse between treatment and planting. The higher rate of tebuthiuron left a residue that virtually sterilized the treated area for up to 261 days. The lower rate of tebuthiuron provided good weed control for 261 days without sacrificing grass gain.

\section{Literature Cited}

Arnold, W.R., and P.W. Santelmann. 1966. The response of native grasses and forbs to picloram. Weeds 14:74-76.

Baur, J.R., R.W. Bovey, and C.R. Benedict. 1970. Effect of picloram on growth and protein levels in herbaceous plants. Agron. J. 62:627-630.

Baur, J.R., and R.W. Bovey. 1975. Herbicidal effects of tebuthiuron and glyphosate. Agron. J. 67:547-553.

Baur, J.R., and R.W. Bovey, and E.C. Holt. 1977. Effect of herbicides on production and protein levels in pasture grasses. Agron. J. 69:846-851.

Bovey, R.W., R.E. Meyer, and H.L. Morton. 1972. Herbage production following brush control with herbicides in Texas. J. Range Manage. 25:136-142.

Bovey, R.W., R.E. Meyer, and E.C. Holt. 1974. Tolerance of bermudagrass to herbicides. J. Range Manage. 27:293-296.

Bovey, R.W., R.E. Meyer, and J.R. Baur. 1975. Evaluation of tebuthiuron for woody plant control. Abstr., Weed Sci. Soc. Amer., p. 22-23.

Flynt, T.O., R.W. Bovey, R.E. Meyer, T.E. Riley, and J.R. Baur. 1976. Granular herbicide applicator for brush control. J. Range Manage. 29: 435-437.

Herr, D.E., E.W. Stroube, and D.A. Ray. 1966. Effect of Tordon residues on agronomic crops. Down to Earth 21:17-18.

Peevy, F.A. 1975. Soil-applied herbicides for upland hardwoods. Proc. So. Weed Sci. Soc. 28:223-225.

Scifres, C.J., and J.L. Mutz. 1976. Evaluation of tebuthiuron for control of South Texas mixed brush. Abstr., Proc. So. Weed Sci. Soc. 29:253.

Stritzke, J.F. 1976a. Selective removal of brush by grid placement of herbicide. Abstr., Proc. So. Weed Sci. Soc. 29:255.

Stritzke, J.F. 1976b. Use of tebuthiuron for control of undesirable vegetation in pastures and range. Abstr., Wecd Sci. Soc. Am., p. 38. 